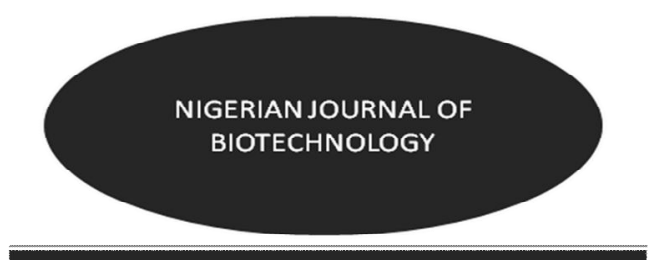

DOI: http://dx.doi.org/10.4314/njb.v29i1.9

\title{
Ameliorative Effect of Different Concentration of Mushroom (Pleurotus Tuberregium) on Pathomorphological Changes Induced By Lead Toxicity in Liver and Kidney of Wistar Albino
} Rats

\author{
Enagbonma, B.J . ${ }^{1,2}$, Tawari-fufenyi, P. ${ }^{1}$, Ekaye, S. ${ }^{1}$ and Osemwegie, $0 .{ }^{3}$ \\ ${ }^{1}$ Department of Environmental Management and Toxicology, Faculty of Life Sciences, University of Benin, \\ P.M.B 1154, Benin City, Nigeria. ${ }^{2}$ Department of Animal and Environmental Biology, Faculty of Life \\ Sciences, University of Benin, P.M.B 1154, Benin City, Nigeria. ${ }^{3}$ Department of Biological Sciences, \\ Landmarks University, Omuraun, Kwara State, Nigeria.
}

\begin{abstract}
This study evaluates ameliorative effect of different concentrations of mushroom (Pleurotus tuberregium) on the effects of lead (Pb). Ninety albino rats were divided into six groups with three replicates (5 rats per group) for 21 days pre-experimental stage for acclimatization. The experimental groups were exposed to $0.1 \mathrm{~g} / \mathrm{I}$ of lead daily for 21 days. At the end of exposure period, lead salt was discontinued for 21 and 42days to verify possible ameliorative effect of mushroom in the post-experimental stage. Samples of liver and kidney tissues were then collected and subsequently analyzed for structural changes every 21 days. The tissues of the pre-experimental stages showed normal tissues as those of the control except in the liver which showed mild periportal chronic inflammatory cell. However, the experimental groups, showed liver with focal periportal vascular congestion and hypertrophy, moderate chronic inflammatory cell infiltration and interstitial oedema. The kidney showed focal proximal tubular necrosis, transmural oedema, interstitial haemorrhage, and chronic inflammatory cell infiltration. The tissues of liver and kidney in the post experimental stages were improved with increased mushroom content in the feed. Results of this study demonstrated that $P$. tuberregium may ameliorate lead toxicity in liver and kidney tissues.
\end{abstract}

(Received 11:03:15; Accepted 28:07:15)

Keywords: Abatement, Albino rat, Kidney and Liver, Lead toxicity, Pathomorphological Pleurotus tuberregium,

Correspondence: benjamin.enagbonma@uniben.edu

\section{Introduction}

Pathomorphological changes induced by lead acetate toxicity in wistar rats has been reported. The main target organs affected are kidney, liver and testes and the lesion are characterized by degeneration, necrosis, cellular and vascular changes (Suradakar et al., 2010). Babalola et al. (2005) observed the distribution of lead in the blood, liver, lung, kidney, heart and brain of albino rats, after oral administration of 1000, 1500 and 2000 ppm of lead solution for 7 consecutive days. Taib et al., (2004) reported that absorbed $\mathrm{Pb}$ is conjugated in the liver and passed to the kidney, where a small quantity is excreted in urine and the rest accumulates in various body organs and affects many biological activities at the molecular, cellular and intercellular levels, which may result in morphological alterations that can remain even after $\mathrm{Pb}$ levels have fallen. Histological evaluation indicate that Liver tissue showed necrosis with depleasion in the glycoprotein granules inside the 
hepatocyte cells, there are no changes in kidney and heart tissue (Sahar, 2014).

Calcium disodium EDTA is a long-established artificial lead expellant but it is lethal to the liver and kidneys. Recently, there have been many studies on the use of natural products such as vitamins and herbal drugs to expel lead ( $\mathrm{Xu}$ et al., 2005). There has been an increase of interest in the therapeutic potential of medicinal plants as antioxidants in reducing free radical- induced tissue damage (Siddique et al., 2000 and Koleva et al., 2002).

Numerous plant products have antioxidant activity as they scavenger free radicals and inhibit lipid peroxidation (Scartezzini and Speroni, 2000 and Tapiero et al., 2002). The oral use of Curcuma longa that has a hepatoprotective effect at $500 \mathrm{mg} / \mathrm{kg}$ daily for 28 days has shown protection against lead induced hepatotoxicity (Baxla, et al., 2013). Supplementation with ginger slightly attenuates the developmental toxicity of fenitrothion or lead (Ahmed et al., 2010).

Pleurotus tuberregium is a tropical sclerotial mushroom that produces a sclerotium or an underground tuber as well as a fruiting body (sporocarp). Both the sclerotium and the mushroom are edible (J in-zhong et al., 2003). Several medicinal properties have been reported in extracts of Pleurotus species. They include antioxidant properties, anti-tumour properties, antigenotoxic, bioantimutagenic activities, antiinflamatory activity, anti-lipidaemic, antihypertensive, and antihyperglycaemic activites, antibacterial and antifungal activities (Fillipie and Umek, 2002; Hu et al., 2006; Ngai and $\mathrm{Ng}, 2006$ ).

This study therefore attempts to investigate the ameliorative effect of different concentration of mushroom (Pleurotus tuberregium) on pathomorphological changes induced by lead toxicity in kidney and liver of wistar albino rats.

\section{Materials and Methods}

Experimental Design: Ninety (90) albino rats were acclimatized for 21days preexperimental stage. There after all the experimental groups were exposed to $0.1 \mathrm{~g} / \mathrm{l}$ of lead daily for 21 days. At the end of exposure period, lead salt was discontinued for 21 days and 42 days to verify possible ameliorative effect of mushroom in the post-experimental stage.
Samples were collected and subsequently analyzed at an interval of 21 days. The 90 Albino rats were divided into six groups with three replicates ( 5 rats per group) in this group order:

Group (1): $90 \%$ of feed $+10 \%$ of Pleurotus tuberregium

(2): $70 \%$ of feed $+30 \%$ Pleurotus tuberregium

(3): $50 \%$ of feed $+50 \%$ Pleurotus tuberregium

(4): $30 \%$ of feed $+70 \%$ Pleurotus tuberregium

(5): Feed $+0.1 \mathrm{~g} / \mathrm{L}$ lead

(6): Control

Histological examination: Tissues of the Liver and Kidney obtained from dissected specimens were fixed in $10 \%$ formalin to arrest metabolic activity in the tissues, avoid autolysis and protein precipitation thus preventing enzymatic digestion of dead tissues. The fixed tissues were passed through several changes of alcohol, 70\% alcohol for 24 hours and $90 \%$ alcohol for 12 hours and through absolute alcohol to remove water from the fixed tissues and allowed complete infiltration of tissues by paraffin. The tissues were then passed through xylene for 3 hours to prevent shrinkage and tissue brittleness in paraffin. After tissue processing, tissues were embedded or blocked out using the leukhand embedded mould. The Lpieces are arranged on an aluminum base to form a rectangle. The molten paraffin was then poured into the moulds and the selected surfaces of the tissues embedded with the aid of a pair of blunt end forceps and allowed to set. The embedded tissues were separated into different blocks and then attached to wooden blocked with the aid of an electric spatula. The blocks were then trimmed using a rotary microtome and knife. At the end of each trimming, the blocks were arranged on ice trays in order to cut thin sections using the rotary microtone at a thickness of 3micron. Section are then collected with help of a camel hair brush and then placed on the slide. Flood picked section with $20 \%$ alcohol in other to spread out fold on the sections and then floated out on a water bath with a temperature 5-10 degree centigrade below the melting point of the wax used. The sections were picked and floated on a water bath and then picked with a pre-labeled slide. The slides were dried on a hot 
plate at a temperature of a 5-10 degree centigrade above the melting point of wax used. These were left on the hot plate for 15 minutes. The staining methods employed in staining the sections were haematoxylin and eosin method to demonstrate general tissue structure and Masson's trichrome method for the demonstration of connective tissue fibre. Dewax in two bathes of xylene for 2 minutes each and hydrate in descending grades of alcohol, absolute: $90 \%, 70 \%$ for 2 minutes each and then wash in water. Stain with enrich haematoxylin for 15minute. Wash excess stains with tap water and differentiate in $1 \%$ acid alcohol briefly. Wash in running tap water and blue for 10 minutes then counter stain in $1 \%$ aqueous eosin for 3 minutes then section washed off in water. Dehydrate through 70\% alcohol, 90\% alcohol and absolute for 2 minutes each. Clear in 2 baths of xylene for 2 minutes and mount with Canada balsam devoid of air bubbles. The specimens were examined and photographed under light microscope Leica DM750, provided with a camera Leica ICC50 (Ross et al., 1989).

\section{Results}

The Liver: Section of the normal liver showed hepatocytes (A) radiating from the central vein and portal triad (B) (Plate 1). Section of the liver With marsh and mushroom (P. tuberregium) only in the diet, showed liver with mild periportal chronic inflammatory (A) and cell infiltration (B) ( Plate 2). When $0.1 \mathrm{~g} / \mathrm{l} \mathrm{Pb}$ was added to experimental diet sectioned liver showed a focal periportal vascular congestion and hypertrophy (A), moderate chronic inflammatory cell infiltration (B) and interstitial oedema (C) (Plate 3). The sectioning of liver of rat fed with marsh and P. tuberregium diet (50:50\%), and treated with $0.1 \mathrm{~g} / \mathrm{l} \mathrm{Pb}$, showed abated liver with normal hepatocytes (A), bile duct (B) and periportal vascular congestion (C) (Plate 4).

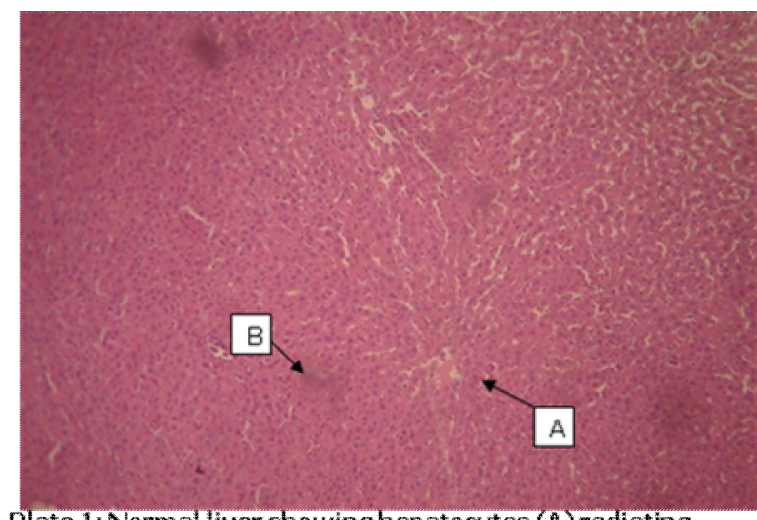

Plate 1 : Normal Wver showing hepatocytes $(A)$ radiating from the central vein and portal triad (B) [H\&Ex40]

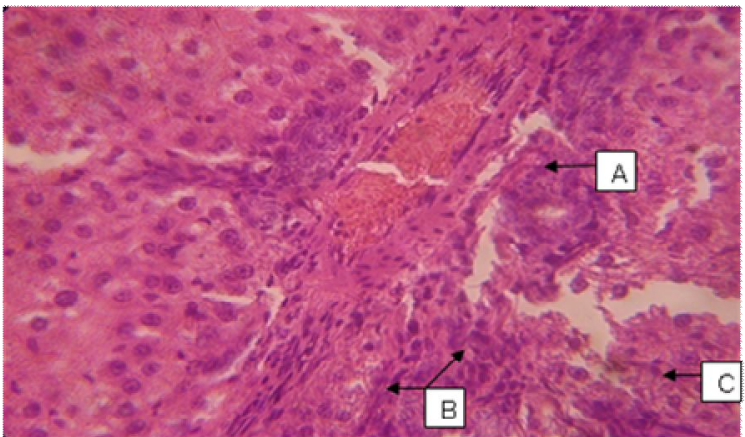

Plate 3: Animal on morsh diet and treated with $0.10 / 1 \mathrm{~Pb}$ showing liver with focel periportel vascular congestion and
hypertrophy (A), moderate dwonic inflammatory cell infiltration (B) and interstitial oedema (C) [H\&E $\times 40]$

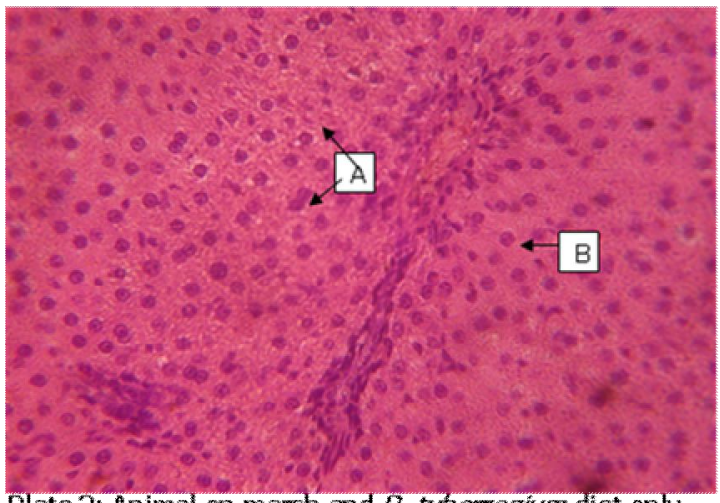

Plate 2: Animal on marsh and $P$, twertegum diet only, showing Live (A) with mild periportal chronic inflammatory cell and infltration (B) $[H 2 E \times 40)$

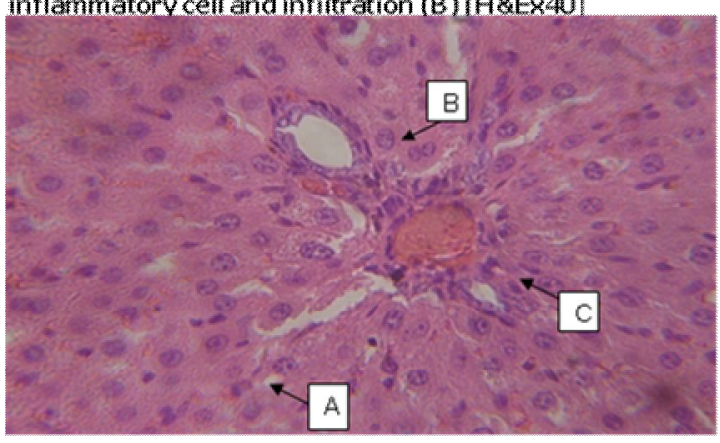

Plate 4lLiver on marsh and $\rho$,tuberreginm diet

(50:50a), and treated with $0.1 \mathrm{~g} / \mathrm{Pb}$, the section of the liver showed abated liver with nomathepatocytes $(A)$, bile duct $(\mathrm{B})$ and periportal vascular congestion (C)[H\&EX40]. 
The kidney: section of the normal kidney showed glomenuli (A), proximal convoluted tubules (B) and distal convoluted tubules (C), are shown (Plate 5). Section of the kidney with marsh and mushroom (P. tuberregium) only the Section of the kidney showed normal kidney with glomeruli (A), proximal convoluted tubules (B) and distal convoluted tubules (C) as represented in Plate 6 below. When $0.1 \mathrm{~g} / \mathrm{l} \mathrm{Pb}$ was added to experimental diet sectioned kidney showed focal

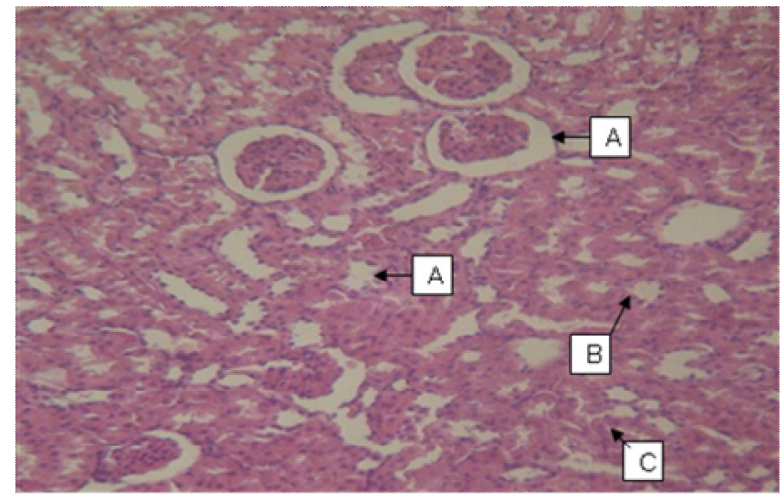

Plate 5: Normal kidney showing glomeruli (A), proximal convoluted tubules (B) and distal convoluted tubules (C) [H\&E $\times 40]$

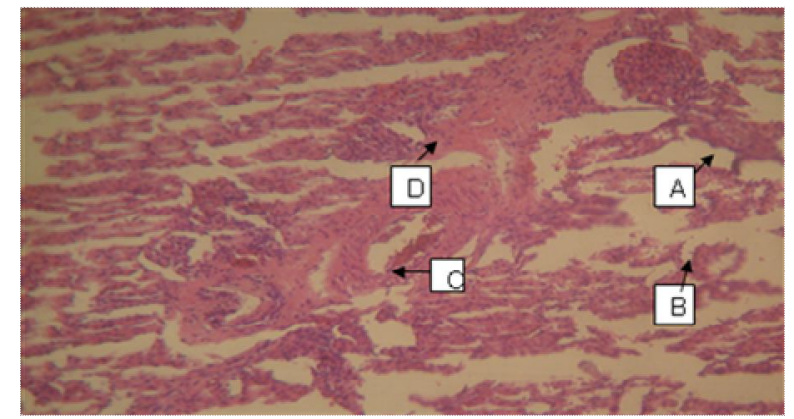

Plate 7: Animal on marsh diet and treated with $0.1 \mathrm{~g} / 1 \mathrm{~Pb}$, showing kidhey with focal proximal tubular necrosis (A), transmuraloedema (B), vascular hypertrophy and congestion (C) and interstitial haemonthage (D) [H\&E X40]

\section{Discussion}

In the pre-experimental stages, rats fed with marsh and mushroom (P. tuberregium) only showed normal tissues like the control. However, the liver showed mild periportal chronic inflammatory cell. Mushroom may cause slight hydropic degeneration of hepatocytes and vacoulations of some hepatocytes and small focal hepatic necrosis (Sanjay and Singh, 2010).

The liver is considered as one of the target organs affected by lead toxicity owing to its proximal tubular necrosis (A), transmural oedema (B), vascular hypertrophy and congestion (C), and interstitial haemorrhage (D) as represented in Plate 7 below. The sectioning of kidney of rat fed with marsh and $P$. tuberregium diet (50:50\%), and treated with $0.1 \mathrm{~g} / \mathrm{l} \mathrm{Pb}$, showed slightly abated kidney with normal glomerulus (A), proximal convoluted tubules (B) and interstitial haemorrhage (C) (Plate 8).

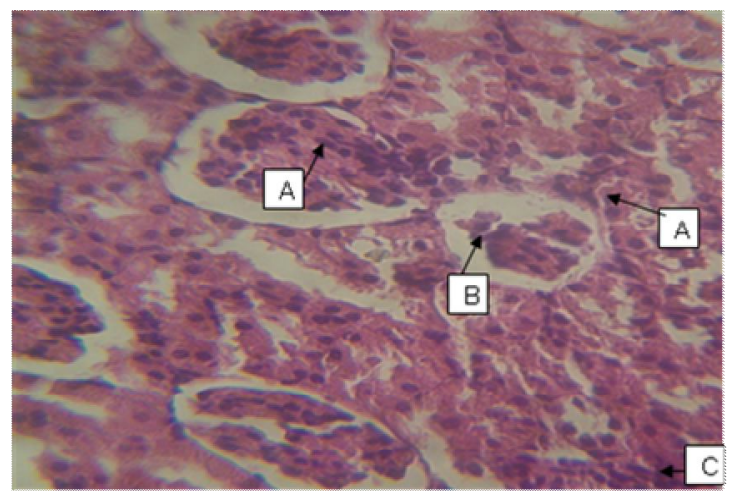

Plate 6: Animal on mersh and $\rho$, tuberregium diet only, showing normal kidney with glomeruli $(A)$, proximal convoluted tubules (B) and distal convoluted tubules (C) [H\&EX4O]

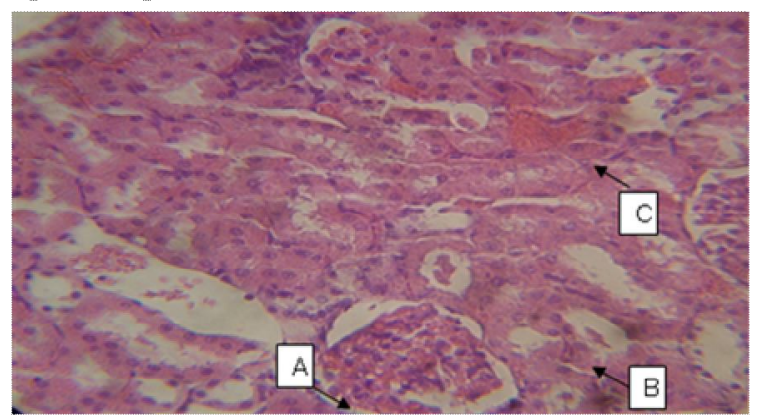

Plate 8: Animal on marsh and $\rho$, twberregüm diet (50:50\%), and treated with $0.1 \mathrm{~g} / \mathrm{Pb}$, showing slightly abated kidney with normal glomeulus ( $A$ ), proximal convoluted tubules $(B)$ and interstitial haemonhage (C) [H\&Ex40]

storage, biotransformation and detoxification in the liver after lead exposure is of relevance in heavy metal poisoning (Herman et al., 2009). The tissues of the liver across all groups in the experimental stages were observed to have liver with focal periportal vascular congestion and hypertrophy, moderate chronic inflammatory cell infiltration and interstitial oedema as shown in Plate 3. In their study Tawari-fufeyin et al. (2008) reported that, the degeneration of histological structure of organs studied; destructions of the blood vessel, epithelium 
linings, infilitration of lymphocytes cum destruction of cell structures of the various tissues may be attributed to the toxic effects of the lead salts deposited in the various tissues.

In the post - experimental stages, there were no improvements with the tissues of the liver fed with $90 \%$ of feed $+10 \% \mathrm{P}$. tuberregium and $70 \%$ of feed $+30 \%$ P. tuberregium. However, slightly abated liver with normal hepatocytes, bile duct and periportal vascular congestion were observed in the group of rats fed $50 \%$ of feed + $50 \%$ P. tuberregium and $30 \%$ of feed $+70 \%$ P. tuberregium as shown in Plate 4 . The presence of iron and vitamin C in P. tuberregium may be the reason for its ability to abate lead from the tissues of rats in this study

In the experimental stages, the tissues of the kidney were seen to have kidney with focal proximal tubular necrosis, transmural oedema, interstitial haemorrhage, and chronic inflammatory cell infiltration as shown in plate 7 . The necrosis of the proximal tubule could be attributed to the inflammatory effects of lead on the walls of the kidney tubules (Tawari-fufeyin et al., 2008). It has been reported that oral dosing of experimental animals with lead induced necrosis, hemorrhage and degenerative changes (Abdel-kalek et al., 2000; Ghorbe et al.. 2001; Elnattat et al. 2003). This is in general agreement with the current study. In the post-experimental stages of this study, there was no improvement with the tissues of the kidney fed with $90 \%$ of feed $+10 \%$ P. tuberregium and $70 \%$ of feed + $30 \%$ P. tuberregium. However, slight abatement in kidney with normal glomenulus, proximal convoluted tubules and interstitial haemorrhage were observed as shown in Plate 8.

Mineral composition analyses indicate that the fruit body of $P$. The presence of iron in the P. tuberregium may be the reason for its ability to abate lead from the tissues of rats in this study. High iron tuberregium is rich in iron and zinc (Ijeh et et al., 2009, Adejumo and Awosanya, 2004). Intake and sufficient iron stores may reduce the risk of lead poisoning in human (Qiang et al., 2007; Wilson et al., 2004). P. tuberregium also contained a level of vitamin $\mathrm{C}$, which has the ability to protect animals from heavy metal poisoning (Null 2006). Other studies with mice, rats, chickens, clams, guinea pigs and turkey all came to the same conclusion that vitamin C protects animals from heavy metal poisoning (Sanjay and Singh, 2010; Norwood et al., 2001; Gajawat et al., 2005). The presence of vitamin $C$ in Pleurotus tuberregium may also be the reason for its ability to abate the concentration of lead from the tissues of rats in this study. It could be concluded that, lead nitrate, at a dose of $0.1 \mathrm{~g} / \mathrm{l}$ induced changes in the kidneys and liver of albino rats, meanwhile the concurrent administration of mushroom (P. tuberregium) can ameliorated the effect of lead nitrate -induced in the tissues at 50\% and above.

\section{Acknowledgments}

I wish to express my heartfelt gratitude to my project supervisor Prof. (Mrs) P. Tawari-Fufeyin. I also acknowledge Dr. O. O. Osemwegie and Dr. S.A. Ekaye for their profound assistance, understanding and constant availability throughout the period of this research. Thanks to all other lecturers in the Department of Animal and Environmental Biology, University of Benin, Benin City, Nigeria for their contribution towards the successful completion of this work.

\section{References}

Abdel-Kalek, M.M., Hosny, G.A. and AbdelRahman, M. (2000). Effect of chronic lead poisoning in broilers J. Comp. Path., And Clinic.Path.13 (2):66- 83.

Adejumo, T.O. and Awosanya, O.B. (2004). Proximate and mineral compositionof four edible mushroom species from south western Nigeria. Afr. J. Biotechnol. 4(10): 1084-1088.

Ahmed, G.A.F., Manal, E.A.E. and Hoda, E.A.F. (2010). Effect of ginger supplementation on developmental toxicity induced by fenitrothion insecticide and/or lead in albino rats. Pesti Biochem and Physiol. 97(3): 267-274.

Babalola, O.O., Ojo, L.O. and Aderemi, M.O. (2005). Lead levels in some biological samples of automechanics in Abeokuta, Nigeria. Indian J. Biochem. Biophys.42:401-403.

Baxla, 1.S., Gora, L.R.H., Kerketta, P., Kumar, N., Roy, B. K. and Patra, P. H. (2013) Hepatoprotective effect of Curcuma longa against lead induced toxicity in Wistar rats. Vet World. 6(9): 664-667. 
El-nattat, W.S., Ali, G.A. and El-Khadrawy, H.H. (2003). The effect of lead acetate and vitamin C (antioxidant) on some enzyme activities in semen and serum of male rabbits. Egypt. J.basic and Appl.Physiol. 2(1): 107- 119.

Fillipie, M., and Umek, A. (2002). Screening of basidomycetes mushroom extracts for antigenotoxic and biomutagenic activity. Die Pharmazie 57: 416-420

Gajawat, S., Sancheti G., and Goyal, P.K.. (2006). Protection against lead induced hepatic lesions in swiss albino mice by ascorbic acid. Pharmacologyonline1: 140-149.

Ghorbe, E., Boujelbene, M., Makni, F., Guremazi, F., Murat, J. and El-Feki, A. (2001). Effect of chronic exposure on kidney function in male and female rats: determination of a lead exposure biomarker. Arch.Physiol.Biochem., 109(5):457463.

Herman, D.S. and Geraldine, M.T. (2009) Influence of minerals on lead- induced alterations in liver function in rats exposed to long-term lead exposure. J Hazard Mater 166: 1410-1414.

Hu, S.H., Chia, V.C., Lien, J.L., Chen, K.S., Lee, M.Y., and Wang, J.C. (2006). Antihyperlipidaemic and antioxidant effects of extracts of Pleurotus cetrinopileatus. J. Agic Food Chem. 54: 21032110

Ijeh, I.I., Okwujiako, I.A., Nwosu, P.C. and Nnodim, H.I . (2009). Phytochemical composition of Pleurotus tuber regium and effect of its dietary incorporation on body /organ weights and serum triacylglycerols in albino mice. Med Plants Res. 3(11): 939-943.

J in-zhong, W.U. and Peter C.K. (2003). Studies on submerged fermentation of Pleurotus tuberregium (fr.) singer part 1: physical and chemical factors affecting the rate of bioconversion efficiency. Food Chemistry. 389393

Koleva, I. I., Van Bleek, T. A., Linssen, J. P., DeGroot, A. and Evstatieva, L. N. (2002): Screening of plant extracts for antioxidant activity: a comparative study on three testing methods. Phytochem Anal. 13(1): 8- 17.
Ngai, P.H. and Ng, T.B. (2006). A Hemolysin from the mushroom Pleurotus eryngii Appl. Microbiol. Biotechnol. 75: 1185-1191

Norwood, J. Jr., Alan, D.L., Donald, L.D. and Gary, E.H. (2001). Residual oil fly ash inhalation in guinea pigs: influence of Abosrbate and Glutathione Depletion. Toxicol Sci.61: 144-153.

Null, G. (2006). Power Foods: The Best Food for Your Health.NAL Hardcover, ISBN 04512197.

Sanjay, M. and Singh, R.B. (2010). Effect of mushroom on the lipid profile, lipid peroxidation and liver function of aging swiss Albino rats. The open Nutra j. 3:248-253.

Qiang, W., Wenjing, L., Wei, Z.Y., Liu, H.X.G., Zhenga, Z.D.W., Zhang, Y.C. and Chen, J. (2007) Iron supplement prevents lead-induced disruption of the blood/brain barrier during rat development. Toxicology and Applied Pharmacology, 219(1):33-41

Ross, M.H, Reith, E.J . and Romrell, L.J . (1989). Histology, A Text Atlas (2nd ed.) Baltimore. Williams \& Wilkins, pp.51- 84.

Sahar H.K. (2014). Morphological changes in liver, kidney tissues of animals' exposure to lead acetate. J of Phama and Bio Sci. 9(1):22-23.

Sanjay, M. and Singh, R.B. (2010). Effect of mushroom on the lipid profile, lipid peroxidation and liver function of aging swiss Albino rats. The open Nutraceuticals joumal.3:248-253.

Scartezzini, P. and Speroni, E. ( 2000). Review on some plants of Indian traditional medicine with antioxidant activity. J Ethnopham. 71(1-2): 23- 43.

Siddique, M.S., Eddeb, F., Mantle, D. and Mendelow, A.D. (2000). Extracts of Ginkgo biloba and Panax ginseng protect brain proteins from free radical induced oxidative damage in vitro. Acta Neurochir. Suppl.76: 87-90.

Suradakar, S.G., Vihol, P.D., Patel, J.H., Ghodasara, D.J., J oshi B.H. and Prajapati, K.S. (2010). Patho-morphological changes in tissues of wistar rats by exposure of lead acetate. Vet world. 3 (2):82-84.

Taib, N.T., Jarra, B.M. and Mubarek, M. (2004). Ultrastructural alterations in hepatic tissues of 
wister rats (Rattus norvegecus) induced by lead experimental toxicity. Saudi J Bio Sci 11: 11-20.

Tapiero, H., Tew, K.D. and Ba, G.N. (2002).

Polyunsaturated fatty acids (PUFA) and eicosanoids in human health and pathologies. Biomed Pharm. 56(2): 200- 207.

Tawari-fufeyin, P. and Akinjokun, A.R. (2008). Haematoxicity and hepatoxicity attributed to zinc and cadmium in Norwegian rat. Toxicol and Envi chem.1(6):531-538.
Wilson, T. K., Phyllis, F. and Richard, D. S. (2004) Interactions between iron deficiency and lead poisoning: epidemiology and pathogenesis. Sci of The Total Environ. 300:21-37.

Xu, Y., Li, G., Han, C., Sun, L., Zhao, R. and Cui, S. (2005). Protective effects of Hippophae rhamnoides $L$. juice on lead- induced neurotoxicity in mice. Biol Pharm Bull. 28(3): 490-494. 